\title{
Facebook as a substitute for kanohi ki te kanohi in the Master of Applied Indigenous Knowledge programme at Te Wānanga o Aotearoa in Māngere
}

This paper will explain the importance of kanohi ki te kanohi and how Facebook has been used as a substitute for kanohi ki te kanohi in the Master of Applied Indigenous Knowledge (MAIK) programme at Te Wānanga o Aotearoa in Māngere. This paper will provide some examples of how Facebook has been beneficial to the MAIK programme.

Because of COVID-19, the Master of Applied Indigenous Knowledge (MAIK) programme was forced to go online, despite being based within and operating from a Māori and Indigenous educational context, which requires the practice of kanohi ki te kanohi. Due to the effects of COVID-19, Facebook was used as a substitute for kanohi ki te kanohi as a means of supporting MAIK students.

In Māori cultural tradition, kanohi ki te kanohi is critical to relationships (O'Carroll, 2013). The physical practice of kanohi ki te kanohi sustains strong kin relationships (Mead, 2016) and is the foundation for many tikanga (O'Carroll, 2013). "Māori have long been early adopters of communications technologies", O'Carroll (2013, p. 271) argues, and digital technologies are no exception. 
Keegan (2000) contends that the Internet affords a virtual space for Māori to share information: "I believe the single greatest factor in the explosion of the Internet was and is peoples' ability to share" (p. 1). While the practice of kanohi ki te kanohi is essential to Māori society, Keegan (2000) claims that new technologies reduce the distance between people by permitting virtual forms of kanohi ki te kanohi to take place. Rather than weaken the cultural practice of kanohi ki te kanohiwhich Keegan (2000) describes as a proverb-digital technologies "makes this proverb even more applicable!" (p. 1).

"Kanohi ki te kanohi", O'Carroll (2013) opines, "sits at the centre of Māori concepts and practices around communication" (p. 4). Digital technologies, therefore, allow Māori to shift "kanohi ki te kanohi practices and rituals to the virtual space to empower their people with the ability and access to participate and engage" (O'Carroll, 2013, p. iii). Indeed, the rituals of tangihanga, for example, "are increasingly applied in virtual spaces as technology continues to advance" (O'Carroll, 2015, p. 201).

The Master of Applied Indigenous Knowledge (MAIK) is a two-year programme that acknowledges the expertise of Indigenous practitioners in particular fields of knowledge and leads them through the process of writing a 15,000-20,000-word exegesis and realising a research-based project that meaningfully contributes to the development of their Indigenous communities (Rangiwai et al., 2020). As the programme is based in a Māori and Indigenous knowledge context, kanohi ki te kanohi, is integral to learning. Indeed, the programme is normally delivered through noho marae and tutorials. COVID-19, however, has been a significant challenge to education and learning (Crawford et al., 2020; Daniel, 2020; Händel et al., 2020; Naciri et al., 2020; Toquero, 2020; Usak et al., 2020) and face-to-face learning, in particular, became a threat to health (Murphy, 2020). As a result, learning moved online very quickly (Alawamleh, 
2020; Daniel, 2020; Händel et al., 2020; Sandars et al., 2020) on an unproven and unmatched scale (Burgess \& Sievertsen, 2020).

Sir John Daniel (2020) avows that the COVID-19 emergency is not the time for institutions to implement complicated distance learning plans but instead that educators should be encouraged to "work with what they know" (p. 3). I am an avid Facebook user, and it is a platform that I know. As a lecturer in the MAIK programme, Facebook has been one of the most powerful tools that I have used in my teaching practice. While standard tools such as the institutional learning management system (iAkoranga) and Zoom have facilitated formal digital learning, Facebook has been used as a substitute for the practice of kanohi ki te kanohi. O'Carroll's (2013) research shows that Māori have used social media as a substitute for kanohi ki te kanohi when necessary, for example, during tangihanga and wānanga. In the MAIK programme, Facebook has enabled the lecturers and class members to stay connected despite the effects of COVID-19.

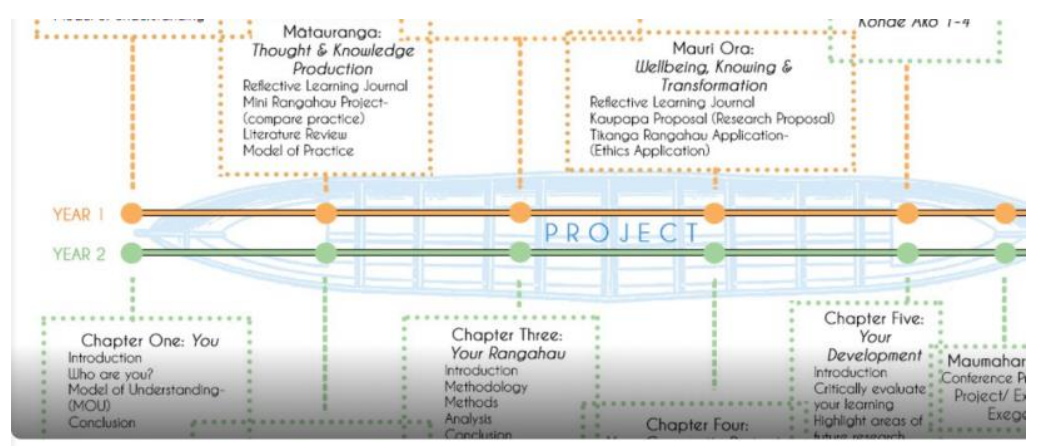

\section{MAIK Māngere Online Learning}

Figure 1: MAIK Māngere Online Learning Facebook group page title and cover photo 
Although social media platforms were not explicitly designed as educational tools, they are nonetheless being adopted and used in this way (Manca, 2020). Facebook, in particular, can be a beneficial and valuable educational tool (Giannikas, 2020; Manickam et al., 2020; Voivonta \& Avraamidou, 2018) primarily when used in conjunction with learning management systems (Giannikas, 2020). When compared with Moodle, Kazanidis et al. (2018) argue that Facebook users have higher levels of social presence (interaction between participants). Furthermore, Facebook groups, in particular, encourage communication between students and create a positive social climate where students interact and share ideas and materials (Kazinidis et al., 2018). Importantly, in a two-year study, Nalbone et al. (2016) discovered that Facebook fosters greater dialogue between teachers and students, helps students adjust to an academic setting, and encourages higher levels of retention.

Facebook allows students to "become autonomous" and to "explore their own potential as learners", "as professionals", and to experience cocreating knowledge in a digital space (Giannikas, 2020, p. 10; Mnkandla \& Minnaar, 2018). For Irwin et al. (2012), integrating Facebook into the learning experience allows more accessibility and flexibility concerning the content, which, in turn, may enrich the quality of learning. Facebook can be used to disrupt the traditional boundaries of education through the implementation of digital teaching and learning in ways that are more social, open, and interactive (Krutka \& Carpenter, 2016; McLoughlin \& Lee, 2010). Facebook may also be used in higher education to support learning, social interaction, and facilitate formal and informal learning (Junco, 2014; Siemens \& Weller, 2011).

The most successful online learning environment, Greenhow and Galvin (2020) opine, is one that includes asynchronous online features; provides students with time and space to work at their own pace; allows students 
to choose what they would like to learn; and to engage frequently in profound learning opportunities with fellow students, teachers, and the subject matter. Since Facebook allows for personal profiling, connections, relationship-building, content creation, and socialising, if considerately integrated into an online learning plan, it can assist students and teachers to remain connected, despite the need for distance with the emergence of COVID-19 (Greenhow \& Galvin, 2020). Social media can "enhance students' engagement and make remote learning seem less remote" (Greenhow \& Galvin, 2020, p. 513).

This paper will now provide some examples of how Facebook has been useful for the MAIK programme.

\section{Facebook Live}

Facebook Live is a real-time live streaming platform that provides users with the ability to broadcast live content (Adedokun et al., 2020; Horsman, 2018; Johnson et al., 2018). Both synchronous and asynchronous, Facebook Live automatically records live broadcasts that can be posted and shared (Adedokun et al., 2020). Facebook Live can be streamed to a private Facebook group, which is beneficial in a learning context (Adedokun et al., 2020; Haimson \& Tang, 2017; Johnson et al., 2018). Another beneficial feature of Facebook Live, concerning learning, is that viewers can participate in the Live by providing comments in the forms of text, images, graphics, interchange format, or emoji (Adedokun et al., 2020). In the MAIK programme, lecturers use Facebook Live to make announcements or explain concepts/assessments, and the video recording remains on the page for students to access again. Students too can use Facebook Live to make announcements or reach out for assistance from fellow students and lecturers. 
Byron Rangiwai was live.

- Admin

- July $24 \cdot \theta$

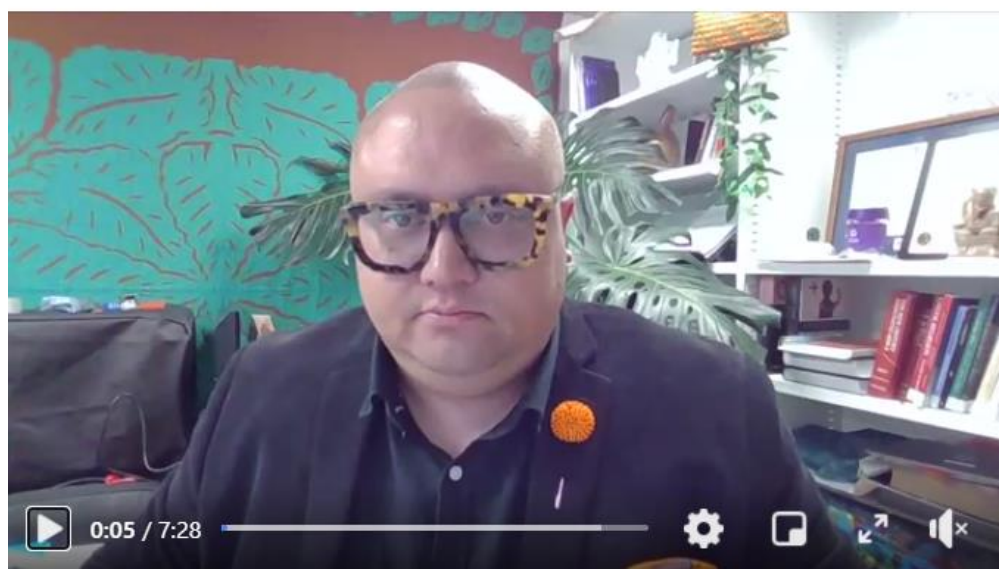

Figure 2: Byron Rangiwai "going live” on Facebook

\section{Polls}

One of the benefits of Facebook polls is that students may feel freer to express their true opinion compared with a face-to-face situation (Salminen, 2014). Polls have been used in the MAIK programme to gauge progress or to ask students what they would like to learn about. 
Byron Rangiwai created a poll.

- Admin

- August $10 \cdot \theta$

How far along are you with Konae Ako 3?

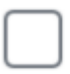

Added by you

I haven't started

$\square$

\section{Added by you}

I've drafted my assessments

Figure 3: Facebook poll

\section{Academic communication}

Facebook can be an effective platform for academic communication; it may increase interaction between students and lecturers; and may be used to promote student-centred learning (Niu, 2019). Information can be shared quickly and efficiently, including diagrams, charts, models, articles, videos, links etc. 


\section{Byron Rangiwai}

- Admin

- September 20 at 3:45 PM - (8)

Although this is an Aboriginal model, it precisely describes the way that we teach. As we want you to be exposed to both Indigenous approaches and Western approaches. Mastery of both sides of the spectrum will give you options nationally and internationally. Our intention is always to give you more opportunities NEVER less. This model is from Ryder et al. (2020, p. 259).

Ryder, C., Mackean, T., Coombs, J., Williams, H., Hunter, K., Holland, A. J. A., \& Ivers, R. Q. (2020) Indigenous research methodology - weaving a research interface. International Journal of Social Research Methodology, 23(3), 255-267.

https://doi.org/10.1080/13645579.2019.1669923

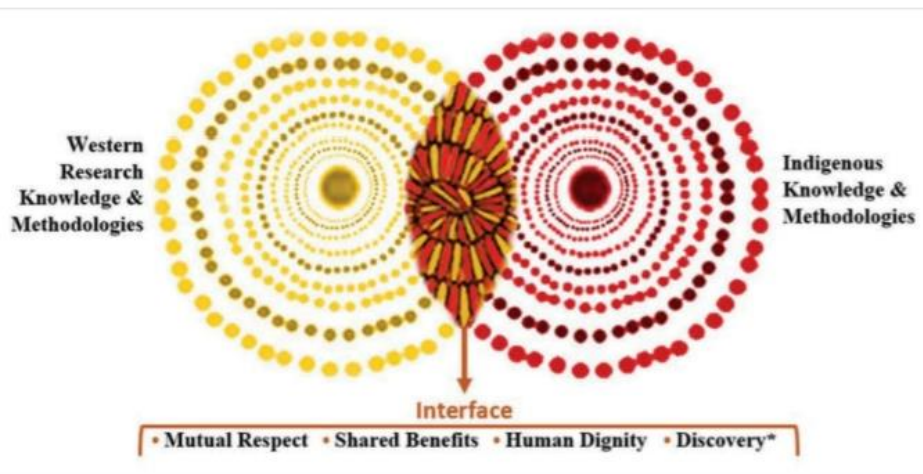

Figure 4: Facebook post about teaching

\section{Other ways Facebook has been used in MAIK}

Facebook can be used to unite the class and collaboratively create and maintain a sense of community. All students have the ability to contribute to the page. Facebook can also be used to encourage learning through quizzes and in other ways. 
Byron Rangiwai shared a link.

O Admin

- August $11 \cdot(-)$

Do this fun (short) quiz on APA 7th and chuck your score below

https://libraryguides.vu.edu.au/apa-referencing/quiz

LIBRARYGUIDES.VU.EDU.AU

libraryguides.vu.edu.au

Figure 5: Facebook post about APA $7^{\text {th }}$ edition quiz

Facebook can be used to uplift and inspire students with quotes, stories, videos, Indigenous news and events, and to share resources such as books and articles. 


\section{Byron Rangiwai}

- Admin

- October 1 at 10:03 AM - (8)

Here is some inspiration!

My ex-student Abann has published his book - based on his project that I supervised. He will launch the book at the end of this month.

Yor, A. K. A. (2020). Native displacement in the twenty-first century: Applying leadership knowledge. Xlibris.

Kia kaha tātou
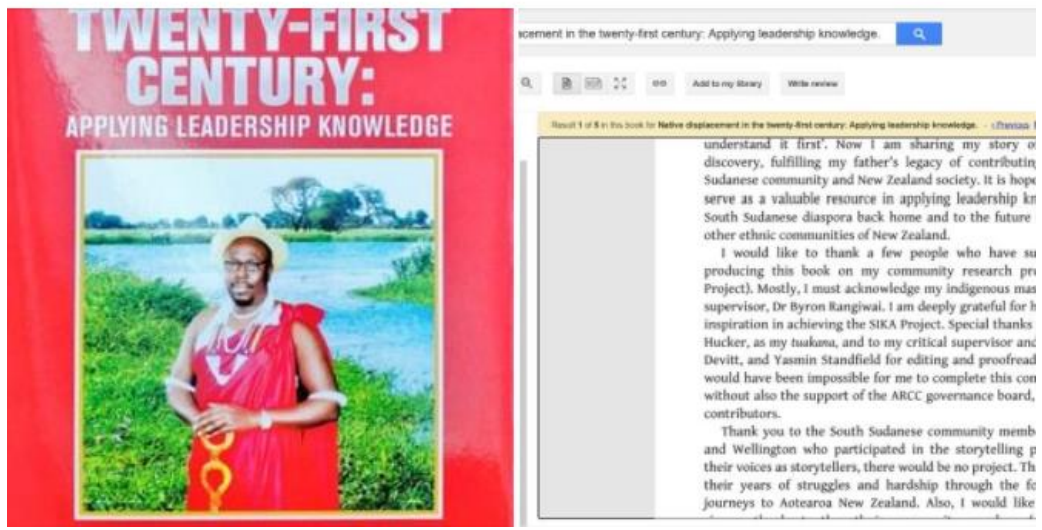

Figure 6: Facebook post about ex-student book publication

Facebook can be used to share new technologies with students that may enhance their learning experiences. 
Byron Rangiwai shared a link.

O Admin

- July $29 \cdot(-8$

The other week I shared an app on this page called tiki-toki. I had to use this app to create a timeline for a master's assignment that I'm doing. The assignment is due in next week but I decided to hand it in today. Here is my attempt at making a timeline. Some of you might find tikitoki fun to use!

https://www.tiki-toki.com/timeline/entry/1463685/5G-History/

TIKI-TOKI.COM

\section{G History}

Figure 7: Facebook post sharing tiki-toki.com ${ }^{1}$

COVID-19 has disrupted the educational and cultural landscape for Māori, and Indigenous students enrolled in the MAIK programme. Kanohi ki te kanohi, as a cultural concept, has been challenged by the advent and spread of the virus. However, innovative practices, such as using Facebook as an online substitute for kanohi ki te kanohi has kept the MAIK class together through hard times and has made communication easier. Without an effective vaccine, COVID-19 will continue to affect our lives (Baker et al., 2020; Durheim \& Baker, 2020; Wilson et al., 2020) which, will, of course, impact on the learning of MAIK students. As with any technology, Facebook must be used critically, and the potential harmful of effects of 24/7 engagement with technology considered and mitigated where possible (Talaei-Khoei et al., 2020). For the near future, however, Facebook will remain part of the MAIK programme in Māngere as a tool for teaching, learning, and communication, and as a

\footnotetext{
${ }^{1}$ Byron is enrolled in the Master of Digital Business programme at the University of Waikato. The use of tiki-toki.com was part of one of the assessments.
} 
substitute for kanohi ki te kanohi, that can be held in the palm of one's hand and accessed at any time. 


\section{References}

Adedokun, O. A., Aull, M., Plonski, P., Rennekamp, D., Shoultz, K., \& West, M. (2020). Using Facebook live to enhance the reach of nutrition education programs. Journal of Nutrition Education and Behavior. https://doi.org/10.1016/j.neb.2020.08.005

Alawamleh, M. (2020). COVID-19 and higher education economics. Journal of Economics and Economic Education Research, 21(2), 1-2. https://searchproquest-

com.ezproxy.waikato.ac.nz/docview/2424655747/c itation/AC1952C05C3148B8PQ/3?accountid=1728 $\underline{7}$

Baker, M. G., Kvalsvig, A., Verrall, A. J., Telfar-Barnard, L., \& Wilson, N. (2020). New Zealand's elimination strategy for the COVID-19 pandemic and what is required to make it work. New Zealand Medical Journal, 133(1512), 10-14.

Burgess, S., \& Sievertsen, H. H. (2020, April 1). Schools, skills, and learning: The impact of COVID-19 on education. VoxEU.

https://voxeu.org/article/impact-covid-19education

Crawford, J., Butler-Henderson, K., Rudolph, J., Malkawi, B., Glowatz, M., Burton, R., Magni, P. A., \& Lam, S. (2020). COVID-19: 20 countries' higher education intra-period digital pedagogy responses. Journal of Applied Learning \& Teaching, 3(1), 9-28. https://doi.org/10.37074/jalt.2020.3.1.7

Daniel, J. (2020). Education and the COVID-19 pandemic. Prospects, 1-6. https://doi.org/10.1007/s11125-020-09464-3

Durheim, D. N., \& Baker, M. (2020). COVID-19-a very visible pandemic. The Lancet, 396(10248), e17. https://doi.org/10.1016/S0140-67369(20)31675-5

Giannikas, C. (2020). Facebook in tertiary education: The impact of social media in e-learning. Journal of 
University Teaching \& Learning Practice, 17(1), 1-13. https://ro.uow.edu.au/jutlp/vol7/iss $1 / 3$

Greenhow, C., \& Galvin, S. (2020). Teaching with social media: Evidence-based strategies for making remote higher education less remote. Information and Learning Sciences, 121(7/8), 513-524. https://10.1108/ILS-04-2020-0138

Haimson, O. L. \& Tang, J. C. (2017). What makes live events engaging on Facebook Live, Periscope, and Snapchat [Paper]. 2017 CHI Conference on Human Factors in Computing Systems, Denver, CO. https://doi.org/10.1145/3025453.3025642

Händel, M., Stephan, M., Gläser-Zikuda, M., Kopp, B., Bedenlier, S. \& Ziegler, A. (2020). Digital readiness and its effects on higher education student socioemotional experiences in the context of COVID-19 pandemic. PsyArXiv, $1-23$. https://doi.org/10.31234/osf.io/b9pg7

Horsman, G. (2018). Reconstructing streamed video content: A case study on YouTube and Facebook Live stream content in the Chrome web browser cache. Digital Investigation, 26, S30-S37. https://doi.org/10.1016/j.diin.2018.04.017

Irwin, C., Ball, L., Desbrow, B., \& Leveritt, M. (2012). Students' perceptions of using Facebook as an interactive learning resource at university. Australasian Journal of Educational Technology, 28(7),

1221-1232. http://www.ascilite.org.au/ajet/ajet28/irwin.html

Johnson, P. T., Thomas, R. B., \& Fishman, E. K. (2018). Facebook live: A free real-time interactive information platform. Journal of the American College of Radiology, 15(1), 201-204. https://doi.org/10.1016/j.jacr.2017.09.008

Junco, R. (2014). Engaging students through social media: Evidence-based practices for use in student affairs. Jossey-Bass.

Kazanidis, I., Pellas, N., Fotaris, P., \& Tsinakos, A. (2018). Facebook and Moodle integration into instructional 
media design courses: A comparative analysis of students' learning experiences using the Community of Inquiry (CoI) model. International Journal of Human-Computer Interaction, 34(10), 932-942. https://doi.org/10.1080/10447318.2018.1471575

Keegan, T. (2000). Tikanga Māori, reo Māori ki te ipurangi: Māori culture and language on the Internet. https://www.cs.waikato.ac.nz/ tetaka/PDF/Tikan gaMaori.pdf

Krutka, D. G., \& Carpenter, J. P. (2016). Why social media must have a place in schools. Kappa Delta Pi Record, 52(1), 6-10.

Manca, S. (2020). Snapping, pinning, liking or texting: Investigating social media in higher education beyond Facebook. The Internet and Higher Education, 44, 1-13. https://doi.org/10.1016/j.iheduc.2019.100707

Manickam, Y., Selvam, N. D., \& Ahrumugam, P. (2020). A study on the impact of collaborative learning on academic performance using Facebook in higher education. International Journal of Advanced Research in Education and Society, 2(1), 15-23. https://myjms.moe.gov/index.php/ijares

McLoughlin, C., \& Lee, M. (2010). Personalised and selfregulated in the web 2.0 era: International exemplars of innovative pedagogy using social software. Australasian Journal of Education Technology, 26(1), 28-43.

Mead, H. M. (2016). Tikanga Māori: Living by Māori values. Huia.

Mnkandla, E., \& Minnaar, A. (2018). The use of social media in e-learning: A meta-synthesis. International Review of Research in Open and Distributed Learning, 18(5), 227-248.

Murphy, M. P. A. (2020). COVID-19 and emergency eLearning: Consequences of the securitisation of higher education for post-pandemic pedagogy. Contemporary Security Policy, 41(3), 492-505. https://doi.org/10.1080/13523260.2020.1761749 
Naciri, A., Baba, M. A., Achbani, A., \& Kharbach, A. (2020). Mobile learning in higher education: Unavoidable alternative during COVID-19. Aquademia, 4(1), 1-2. https://doi.org/10.29333/aquademia/8227

Nalbone, D. P., Kovach, R. J., Fish, J. N., McCoy, K. M., Jones, K. E., \& Wright, H. R. (2016). Social networking web sites as a tool for student transitions: Purposive use of social networking web sites for the first-year experience. Journal of College Student Retention: Research, Theory \& Practice, 17(4), 489-512. https://doi.org/10.117/1521025115579253

Niu, L. (2019). Using Facebook for academic purposes: Current literature and directions for future research. Journal of Educational Computing Research, 56(8), 1384-1406.

https://doi.org/10.1177/07356331145161

O'Carroll, A. D. (2013). Kanohi ki te kanohi-a thing of the past? An examination of Mãori use of social networking sites and the implications for Māori culture and society [Doctoral thesis]. Massey University. https://mro.massey.ac.nz/handle/10179/5323

O'Carroll, A. D. (2015). Virtual tangihanga, virtual tikanga: Investigating the potential and pitfalls of virtualising Māori cultural practices and rituals. The Canadian Journal of Native Studies, 35(2), 183-206.

Rangiwai, B., Simati-Kumar Chand, B., \& Mataroa, R. (2020). The impacts of COVID-19 on the 2020 cohort of the Master of Applied Indigenous Knowledge programme at Te Wānanga o Aotearoa in Māngere. Te Kaharoa: The eJournal on Indigenous Pacific Issues, 15(1), $1-21$. https://doi.org/10.24135/tekaharoa.v15i1.301

Salminen, J. (2014). Leveraging Facebook as a peersupport group for students. In $\mathrm{V}$. Benson \& $\mathrm{S}$. Morgan (Eds.), Cutting-edge technologies and social 
media use in higher education (pp. 195-212). IGI Global.

Sandars, J., Correia, R., Dankbaar, M., de Jong, P., Goh, P. S., Hege, I., Masters, K., Oh, S., Patel, R., Premkumar, K., Webb, A., \& Pusic, M. (2020). Twelve tips for rapidly migrating to online learning during the COVID-19 pandemic. MedEdPublish. https://doi.org/10.15694/mep.2020.000082.1

Siemens, G., \& Weller, M. (2011). Higher education and the promises and perils of social network. Revista de Universidad y Sociedad del Conocimiento, 8(1), 164170.

Talaei-Khoei, A., Daniel, J., \& Dokhanchi, M. (2020). Can Facebook improve students' engagement in flipped classes? Community of Inquiry approach. Proceedings of the 53 ${ }^{\text {rd }}$ Hawaii International Conference on System Sciences (pp. 3-11). University of Hawaii.

https://doi.org/10.24251/HICSS.2020.003

Toquero, C. M. (2020). Challenges and opportunities for higher education amid the COVID-19 pandemic: The Philippine context. Pedagogical Research, 5(4), 1-5. https://doi.org/10.29333/pr/7947

Usak, M., Masalimova, A. R., Cherdymova, E. I., \& Shaidullina, A. R. (2020). New playmaker in science education: COVID19. Journal of Baltic Science Education, 19(2), 180-185. https://doi.org/10.33225/jbse/20.19.180

Voivonta, T., \& Avraamidou, L. (2018). Facebook: A potentially valuable educational tool? Educational Media International, 55(1), 34-48. https://doi.org/10.1080/09523987.2018.1439708 Wilson, N., Telfar-Barnard, L., Kvalsvig, A., Verral, A., Baker, M., \& Schwehm, M. (2020). Modelling the potential health impact of the COVID-19 pandemic on a hypothetical European country. medRxiv, 1-15. https://doi.org/10.1101/2020.03.20.20039776 